future construction of scientific instruments. They are being marketed by International Technical Developments, Ltd., Thames House, Millbank, London, S.W.1.

\section{The Wettest Place in the British Isles}

Dr. J. Grasspoole, in an article entitled "The Wettest Place in the British Isles", which appears in the Meteorological Magazine of July, seeks to end the false idea so commonly held that Seathwaite, in Borrowdale, is the wettest place in Great Britain. $\mathrm{He}$ points out that there are several small areas nearly twice as wet as Seathwaite, and suggests that the common error has lasted so long because meteorological literature has not provided definite figures to disprove it. This lack of precise information has been due to the lack of rain gauges near the summits of the highest mountains in the four wettest areas over which the average annual rainfall exceeds 150 inches-areas in Snowdonia, the English Lake District, on Ben Nevis, and at the head of the River Garry in the western highlands of Scotland. Dr. Glasspoole considers that in the light of records now available and a study of the relationship between average rainfall and the configuration of the land, estimates can be made of the maximum rainfall in each of the four areas. In Snowdonia we have Glaslyn, at 2,500 feet, with 198 inches, which is probably a little less than the figure for the summit, only about 500 yards away. In the Lake District it is thought that 185 inches is not exceeded in the wettest area, which includes Scafell and Scafell Pikes, while Ben Nevis, in spite of its greater elevation, is more isolated and in consequence offers less obstruction to the moisture-bearing winds, and its summit has a rainfall estimated at only about 165 inches. At the head of the River Garry, however, the fall on Sgurr na Ciche is thought to be comparable with that of the summit of Snowdon over a small area, namely, about 200 inches, compared with the 129 inches of Seathwaite Farm, which last is not even the wettest habitation in Great Britain.

\section{Fortified Hill-top Site in Sussex}

A Fortified hill-top site on Mount Caburn, one mile north of Glynde, near Lewes, has been partially excavated by Dr. A. E. Wilson of Brighton Grammar School with the assistance of Dr. E. Cecil Curwen. Since July, it is reported in The Times of September 14, portions of the outer and inner ramparts and a length of Iron Age road, with three gateways, have been uncovered. Of the gateways, one on the north side of the town, where the slope is comparatively easy, is of considerable size and is provided with reentrant ramparts on either side for purposes of defence. A number of sling stones were found. The steep slope of the south side was defended by ramparts and a deep ditch. There are indications in the ceramic evidence that the site was first occupied about 500 B.c., and was fortified about two hundred years later. Stratification revealed by trenching suggests two periods of reconstruction, one about 50 B.c., when the main gate was moved a few feet forward, and a second about one hundred years later, when a second gate, forming a sort of barbican, was added. Piles of ash near this gate may be, it is conjectured, either a relic of the process of hardening the ends of oak stakes to be driven into the ground, or evidence that the town was destroyed by fire. Flint kerbs mark the edges of the Iron Age roadway, of which the surface is reinforeed by flints at a distance of four feet six inches apart, indicating that the gauge of the prehistoric cart was approximately the same as that of the modern cart. One of the ramparts shows what appears to be an early attempt to mix a concrete, powdered chalk apparently being mixed with water and rubble. A grant of $£ 20$ made by the Sussex Archæological Society has made it possible to continue the work of excavation until the end of October.

\section{Prehistoric Finds at Glasgow}

Evidence, it is claimed, indicating the site of a wooden circle, or temple, the largest of its kind yet known, has been found at Knappers, on the Dumtocher Boulevard, Glasgow. The site has been under investigation for some weeks by $\mathrm{Mr}$. Ludovic $\mathrm{Mc}$ Lellan Mann and Capt. Robert Bush Black, the proprietor of the land. The circle, it is reported in The Times of September 15, has a radius of $86 \mathrm{ft}$., the ground plan being revealed by the socket-holes which held the wooden posts and showing a sym. metrical arrangement, "involving circles, ellipses and a large number of serpentine figures". A cemetery adjoins the circle containing fifty-three burials, both cremated and inhumed, with grave furniture and stone settings, many of which are said to be of an unusual nature. The associated funerary vessels fall into four classes and indicate both stone and bronze age datings. For the further exploration of the site financial assistance is required. Should this be adequate the site will be preserved and the monument reconstructed. Donations should be addressed to Mr. J. Eric Fergusson, 166 Buchanan Street, Glasgow.

\section{Educational Films}

From the British Film Institute we have received three lists, intended for the use of teachers, of about a thousand $16 \mathrm{~mm}$. films : "Geography Teaching and Travel" (about 600), "Science" (400) and "History" (30). Against the title of each is shown its length, whether silent or sound, reference to report, if any, in the Institute's monthly film bulletin, and name and address of distributor. A large majority of the films are silent. Among the sound films are thirty "road-shows" obtainable through Sound-Services, Ltd., which provides a complete projection service in combination with the hire of films. The other sources of supply are very various : camera makers (Kodak, etc.), trade publicity organizations (Australian and Canadian), railway and other travel agencies (L.M.S., Scottish, German, Dutch), firms specializing in educational films such as British Instructional Films, Ltd., Educational Films Bureau, Educational and General Services, Ltd., Gaumont-British Equipment, Ltd., Visual Education, Ltd., and Dance-Kaufmann Technical Films; also the Empire Film Library, 